\title{
Differences in Effectiveness between Well Water and Hay Infusion Water as Ovitrap of Mosquitoes Larvae
}

\author{
Supriyadi", Nina Indriyawati, Rodhi Hartono, M.Syamsul Arif, Shobirun \\ PoltekkesKemenkes Semarang. Jln. TirtoAgung Pedalangan, Banyumanik, Semarang 50239, Indonesia
}

*Corresponding Author: Supriyadi, PoltekkesKemenkes Semarang. Jln. TirtoAgung Pedalangan, Banyumanik, Semarang 50239, Indonesia, Email: priex76@yahoo.com

\begin{abstract}
Background: Prevention efforts have been made to eradicate mosquito breeding, larvae examination but the results have not been optimal. Therefore, larval source reduction program and mobilize the health sector participation is critical.
\end{abstract}

The Objective: The purpose of research to determine the effectiveness of the prevention of Dengue Hemorrhagic Fever (DHF) by utilizing the waste for ovitrap in Semarang City Elementary School.

Method: This research was a quasy experiment with the design of a post-test study design. The subjects were 75 elementary schools in the District Tembalang, Gajah Mungkur, and Semarang.

Result: The results showed that there was no difference in the rate of House Index, Container Index, Breteau Index and Free-Larva Numbers on modified fresh water, hay infusion ovitrap placed indoor and outdoor. The results of the post-hoc test found a significant difference between the modified ovitrap consist of fresh water and hay infusion on the number of larvae that were caught.

Conclusion: It is recommended that communities should play an active role in eradicating the mosquito by breaking the cycle of life of the mosquito.

Keywords: Well water, Hay infusion water, Ovitrap, Mosquito larvae

\section{INTRODUCTION}

Dengue Hemorrhagic Fever is still one of Indonesia's public health problems with increasing number of patients with widespread dispersal. Despite the recent incidence of dengue fever in adulthood, dengue fever is most common in children, especially at school age.

Schools are a learning place for children to increase knowledge for their future but it is undeniable that the surrounding school environment has the potential to become a source of Aedesaegepty mosquito breeding. Implementation of clean and healthy behavior in the school environment so far must be recognized not entirely runs as expected.

Large classroom setting with trees, many classrooms and bathrooms, and puddles that cannot be controlled cause less effective problems in the eradication of mosquito larvae. Therefore, the program of reducing larval sources and gaining the participation of the nonhealth sector becomes very important.
Installation of ovitrap by utilizing waste (used goods such as bottles or plastic glass of mineral water around the school environment is useful to cut the life cycle of Aedesaegypti mosquito larvae without insecticides (chemicals).

From several phenomena mentioned above, it is necessary to examine the role of ovitrap to the termination cycle of Aedesaegypti mosquito breeding in Elementary School of Semarang City. The purpose of this research is to know the effectiveness of indoor and outdoor ovitraf waste utilization on the number of larvae trapped in elementary school area of Tembalang, Gajah Mungkur and South Semarang sub-districts, Semarang City.

\section{Materials ANd Methods}

The type of research used is a quasiexperimental experiment. The design of this study is post-test only design. The subjects in this study were Aedesaegypti mosquito larvae collected at Elementary School in Tembalang Sub-district (33 samples), Gajah Mungkur (18 
samples) and South Semarang (24 samples). Each school is installed six ovitrap units consisting of 3 ovitrap mounted in the classroom and three ovitrap installed in the bathroom/school environment.

Aedesaegypti breeding data obtained by observation of three indoor and outdoor ovitrap to larvae. The indoor and outdoor ovitraps have different media: well water, 5\% hay infusion water and $10 \%$ hay infusion water. The larval density of the field is calculated based on larvae Index- Free-Larva Numbers (FLN), House Index (HI), Container Index (CI) and Breteau Index (BI). The larvae were observed three times for four months.

Bivariate analysis was performed by Mann Whitney test to determine the different density of Aedesaegypti larvae on modified ovitrap. Kruskal Wallis test is used to compare three types of attractants placed either indoor or outdoor.

\section{RESULT AND DISCUSSION}

The results of research concern with the physical and biological environment such as water reservoirs for daily needs, the number of decorative plants and shade.

Table1. Distribution of observations on physical and biological environments.

\begin{tabular}{|l|l|l|l|}
\hline & Tembalang & $\begin{array}{l}\text { Gajah } \\
\text { Mungkur }\end{array}$ & Semarang \\
\hline Shading & 14 & 10 & 13 \\
\hline $\begin{array}{l}\text { Water } \\
\text { reservoirs }\end{array}$ & 33 & 18 & 24 \\
\hline $\begin{array}{l}\text { Decorative } \\
\text { plants }\end{array}$ & 16 & 9 & 18 \\
\hline Fish pond & 7 & 0 & 3 \\
\hline
\end{tabular}

The results showed that the presence of water reservoirs for daily use with a high enough rate because it is used for everyday purposes such as bathing, urinating and for other purposes. Aedesaegypti mosquitoes are more interested in putting their eggs in the dark, colorful places, mainly black, wide open, and especially those located in areas protected from direct sunlight (Depkes RI, 2001).

Ornamental plants both in the primary area of Tembalang, Gajah Mungkur and South Semarang subdistrict relatively little, but the garden is still found quite a lot. Ornamental plants and garden plants are places that Aedesaegypti mosquitoes like to rest/hide. According to Soegijanto, (2006), the number of ornamental plants and yard plants will affect the humidity and lighting in the class and the garden. When a lot of ornamental plants and garden plants found, this condition will add a place that is preferred by mosquitoes to rest and also add to the age of mosquitoes.

The results of this observation can illustrate that the biological and physical environments in the observed elementary school have the potential to become Aedesaegypti mosquito breeding grounds.

Table2. Type of control performed.

\begin{tabular}{|l|l|l|l|}
\hline & Tembalang & $\begin{array}{l}\text { Gajah } \\
\text { Mungkur }\end{array}$ & Semarang \\
\hline $\begin{array}{l}\text { Mosquitoe } \\
\text { coil }\end{array}$ & 1 & 0 & 0 \\
\hline $\begin{array}{l}\text { Mosquito } \\
\text { spray }\end{array}$ & 1 & 0 & 0 \\
\hline $\begin{array}{l}\text { Electric } \\
\text { racket }\end{array}$ & 1 & 0 & 0 \\
\hline Repellent & 3 & 0 & 2 \\
\hline Bath drain & 17 & 4 & 5 \\
\hline Abatisation & 5 & 2 & 0 \\
\hline Others & 3 & 2 & 2 \\
\hline
\end{tabular}

Efforts to control the vector have been made by the elementary school communities of Tembalang, Gajah Mungkur and Semarang Selatan sub-districts such as cleaning mosquito nests (and environmental hygiene). The school communities in controlling Aedesaegypti mosquito vectors apply poison and non-toxic types. Types of toxins used included a kind of burn and sprayed while control of non-toxins includes electric rackets, repellents, etc. Some elementary school residents use the bathtub drain, and abatisation but only a small part of the primary school using vector control naturally by wearing trousers.

The results of this study indicate that the residents of the school are very diverse in controlling the vector of Aedesaegypti mosquitoes. Although primary education residents have attempted to control mosquito vectors of various types, both toxic and nontoxic, they are ineffective in preventing the bite of Aedesaegypti mosquitoes because a small part is done during the day. It can be concluded that most of the elementary school still lack understanding in controlling Aedesaegypti vectors. Likewise, in managing to break the life cycle chain of Aedesaegypti mosquito vector, the primary school residents did not perform well because only a few elementary school residents declared routinely to drain the tub. 
The number of trapped larvae calculated by HI, CI, BI and FLN showed high values both on modified ovitrap with attractants of well water, $5 \%$ hay water infusion and $10 \%$ hay water infusion. The mean values of HI, CI, BI and FLN for well water wells were 25.51, 25.51, 25.51 and 74.49 and for 5\% water hay infusion as well as $10 \%$ water hay infusion respectively of 35.82, 35.82, 35.8264 .18 and 39.56, 39.56, $39.56,60.44$. This figure indicates that the population of primary schools that contain dengue mosquitoes is quite high. According to the Depkes (minister of Health) RI (2001), the House Index figure considered safe for dengue fever transmission is $<5 \%$. Thus elementary schools in Tembalang, Gajah Mungkur, and South Semarang subdistricts are vulnerable to DHF. The results of this study found that the presence of mosquitoes transmitting disease Aedesaegypti Primary School in three districts was in high numbers. Such circumstances can occur considering the environment in these primary schools is an environment with a dense population with adjacent building houses and the environment around quite a lot of untreated plants. Also, the topography of Tembalang, Gajah Mungkur and South Semarang with a height of 90-200 Meter (below 1000 meters) from the sea surface which is very vulnerable to the development of Aedesaegypti mosquitoes.

Environmental temperature in Tembalang, Gajah Mungkur and South Semarang subdistricts ranges from 25 degrees Celciusto 30, humidity 62\% - 84\% (Samadikun, 2009). Furthermore, the type of construction of the school buildings is quite diverse. According to DepkesRI (2001), the environmental temperature, type of house construction, materials and building ventilation have a significant effect on micro-climate change in the room.

The results of the Container Index and Breteau Index results obtained a high score. This condition indicates that in elementary school of Tembalang, Gajah Mungkur and South Semarang sub-districts are very potential to spread dengue disease caused by Aedesaegypti. According to Kantachuvessiri (2002), CI rate above $10 \%$ and BI above $50 \%$ are very potential for the spread of dengue disease. The BI rate is the most informative index of larvae because it contains the relationship between the house and the active shelter. This index is particularly relevant for focusing control efforts on the most common management or habitat destruction and orientation for educational messages in activities undertaken by the community (WHO, 2001).

Free Number of larvae (FNL) on modified ovitrap with well water, $5 \%$ hay water infusion and $10 \%$ hay water infusion placed indoor and outdoor show value less than $95 \%$. The results of this study indicate that the success rate in mosquito nets eradication activities is still low based on Healthy Indonesia Indicator 2010. According to the DepkesRI (1992), the benchmark of achievement in the elimination of mosquito nests dengue is with FNL indicator of at least $95 \%$.

The result of analysis with Mann Whitney statistic test number of larvae trapped in modified ovitrap containing well water, $5 \%$ hay infusion water and $10 \%$ hay infusion water with indoor and outdoor placement got p-value = $0.988,0.387$ and 0.897 ( $p>0.05$ ). These results indicate that there is no significant difference between modified ovitrap containing those attractants. Placement of modified ovitrap both indoor and indoor shows the similarity that both indoor and indoor placement both have a good function to catch and to identify larvae of Aedesaegypti. Although the statistics test is not differing significantly but descriptively the placement of modified ovitrap outdoor is relatively more than in the indoor installation. The results of this study are supported by Hasyimi (2000) research which concluded that the acquisition of AedesAegypti eggs on ovitrap is placed out more than in the house. Other previous studies conducted by Lestari (1991) and Hasyimi (1993) also concluded that the acquisition of AedesAegypti eggs in the ovitrap is laid out more than in the home.

The result of the post-hoc test of difference of well water attractants with $5 \%$ and $10 \%$ hay infusion water obtained $\mathrm{p}$ value $=0.029(\mathrm{p}$ $<0.05$ ). This number indicates the attractiveness of the $5 \%$ water of the hay has a stronger appeal than the standard water to Aedesaegypti mosquitoes. This condition is due to the attractiveness of the fermentation (soaking) of straw water contains $\mathrm{CO} 2$ and ammonia compounds that give rise to the attraction of Aedesaegypti mosquitoes (Santana, 2006).

According to Kawada (2007), attractiveness is something that has appeal to insects (mosquitoes) both chemically and visually (physically). The chemical attractants may be ammonia, CO2, lactic acid, octanol, and fatty 
acids. The substance or compound is derived from an organic material or is the result of metabolic processes of living things, including humans. $\mathrm{CO} 2$, lactic acid, and ethanol are excellent attractants for mosquitoes. The aroma of fatty acids produced by normal skin flora is effective at a distance of 7-30 meters that can even reach 60 meters for several species (Foster, 2002). Physical attractiveness can be a vibration of sound and color, either the color of the place or the light. The function of attractants is to directly influence behavior, monitor or reduce mosquito populations, without causing injury to other animals and humans, and leaving no residue in food.

The results of this study differ from the results Polson et al. (2002) using a water concentration of $10 \%$ straw, and Santos et al. (2003) with various concentrations showed that straw water with a concentration of $10 \%$ to produce eggs caught the most. Santana et al. (2006) using an attractant with a kind of fermented water grass leaves also produce eggs of Aedes trapped more than plain water (tap water). According to Dekker (2005) that water immersion of hay and fermentation of grass produce $\mathrm{CO} 2$ and ammonia; a compound that proved to affect the smell of Aedes mosquitoes. Results of other studies with different results conducted by Sayono (2008) mentions that the mosquito Aedesaegypti more trapped in ovitrap with tiger prawn water attractant than $10 \%$ hay immersion and water.

\section{CONCLUSION}

The results of research conclude that the description of the biological and physical environment has the potential to be a nesting and breeding of Aedesaegypti in elementary schools located in the area ofTembalang, Gajah Mungkur, and South Semarang sub districts. The control of the Aedesaegypti mosquito vector is largely inadequate and the small effort of the elementary public communities to eradicate mosquito breeding. The mosquito density index on modified ovitrap: HI, CI, and BI, as well as the Free Rate of larvae, are found with high numbers. There is a significant difference between modified ovitrap contains: well water and hay water immersion with $\mathrm{p}$ value $=0.029 \quad(\mathrm{p}<0,05)$. Based on the conclusions, it is suggested the need to improve both the biological and physical environment to prevent mosquito breeding by cleaning the environment on a regular basis. Improved vector control to prevent the potential transmission of DHF can be done by using non-toxic materials such as mosquito nets, electric rackets and so forth.

\section{REFERENCES}

[1] Dekker T, Geier M, Cardé RT. 2005. Carbon dioxide Instantly Sensitizes Female YellowFever Mosquitoes to Human Skin Odours. The Journal of Experimental Biology 208: $2963-2972$

[2] DepkesRI.1992.PetunjukTeknisPemberantasan NyamukPenularPenyakit DBD, Ditjen P2M \& PLP. Jakarta: Depkes RI, 2001. PedomanEkologidanAspekPerilakuVektor, Ditjend. P2M \& PL, Depkes RI. Jakarta

[3] Foster WA, Walker ED. 2002. Medical and Veterinary Entomology. Edited by Gary Mullen dan Lance Durden. London: Academic Press. P 203-233

[4] Hasyimi, M. Enny W. Lestari danSupratman S. (1993).KesenanganbertelurAedesaegyptispesies . MajalahSanitasi. Vol.II N0. 3 h. 163-165.

[5] Kantachuvessiri, A., 2002. Dengue Hemorrhagic Fever in Thai Society. The Southeast Asian. Journal of Tropical Medicine and Public Health. Vol 33 No.1, Maret 2002, p4-10.

[6] Kawada H, Honda S, Takagi M. 2007. Comparative Laboratory Study on the Reaction of Aedesaegypti and Aedesalbopictus to Different Attractive Cues in a Mosquito Trap, J.MedEntomol 44 (3): 427-432

[7] Lestari, E.W. Hasyimi, M. danSupratman. (1991).Penggunaanovitrapuntukpemantauanpop ulasiAedesaegypti di Jakarta Pusat. Pros. Kongg. Dan Seminar Biologi Vol. II. Hal 148153

[8] Polson KA, Cutis C, Seng CM, Olson JG, Chanta N, Rawlins SC. 2002. The Use of Ovitrap Baited with Hay Infusion as a Surveillance Tool for Aedesaegypti Mosquitoes in Cambodia. Dengue Bulletin Vol. 26: 178184

[9] Santa'ana AL, Roque RA, danEirasAE . 2006. Characteristics of Grass Infusion as Oviposition Attractants to Aedes (Stegomya) (Diptera: Culcidae). J Med Entomol Vo. 43: 214 -220

[10] Santos, SRA, Melo-Santos MAV, Regis L dan Albuquerque CMR. 2003. Field Evaluation of Ovitrap with Grass Infusion and Bacillus thuringiensisvarisraelensis to Determine Oviposition rate of Aedesaegypti. Dengue Bulletin Vol 27: 156-162.

[11] Sayono.(2008).PengaruhModifikasiOvitrapterh adapJumlahNyamukAedesyangTertangkap.unp ubhised. Diaksestanggal 10 Agustus 
Differences in Effectiveness between Well Water and Hay Infusion Water as Ovitrap of Mosquitoes Larvae

(2012).http://eprints.undip.ac.id/18741/1/Sayon o.pdf.

[12] Soegijanto. 2006. DemamBerdarah Dengue edisikedua. Airlangga University Press. Surabaya
[13] WHO.2001.PanduanlengkapPencegahan\&Peng endalian Dengue \& DBD (AlihBahasa: PalupiWidyastuti), Regional Office for South East Asia Region, World Health Organization, New Delhi

Citation: Supriyadi, Nina Indriyawati, Rodhi Hartono, Syamsul ArifM, Shobirun. Differences in Effectiveness between Well Water and Hay Infusion Water as Ovitrap of Mosquitoes Larvae. ARC Journal of Public Health and Community Medicine.2017; 2(4):8-12: dx.doi.org/10.20431/ 2456-0596.0204002

Copyright:(C) 2017 Authors. This is an open-access article distributed under the terms of the Creative Commons Attribution License, which permits unrestricted use, distribution, and reproduction in any medium, provided the original author and source are credited. 